\title{
SUPERVISI AKADEMIK KEPALA SEKOLAH DAN MOTIVASI KERJA GURU DALAM KINERJA MENGAJAR GURU
}

\author{
Oleh: \\ Saidah, Tjutju Yuniarsih, Eka Prihatin \\ Universitas Pendidikan Indonesia \\ (E-mail: saidahmaleek@gmail.com)
}

\begin{abstract}
ABSTRAK
Permasalahan rendahnya kinerja mengajar guru yang disebabkan oleh kurang efektifnya supervisi akademik kepala sekolah dan motivasi kerja guru. Tujuan penelitian ini adalah untuk mengukur pengaruh supervisi akademik kepala sekolah dan motivasi kerja guru terhadap kinerja mengajar guru. Metode penelitian: analisis deskriptif, pendekatan kuantitatif, teknik analisis menggunakan korelasi product moment, determinasi dan regresi. Pengumpulan data melalui angket. Populasi dalam penelitian ini yaitu guru-guru SMK Negeri di Kota Bandung, sedangkan unit analisis menggunakan pengambilan sampel dengan teknik probability sampling. Hasil analisis menunjukkan bahwa supervisi akademik kepala sekolah terhadap kinerja mengajar guru berkorelasi positif sangat kuat. Motivasi kerja guru terhadap kinerja mengajar guru berkorelasi positif sangat kuat. Supervisi akademik kepala sekolah dan motivasi kerja guru terhadap kinerja mengajar guru secara simultan berkorelasi positif sangat kuat. Kesimpulannya, terdapat pengaruh positif yang signifikan antara supervisi akademik kepala sekolah dan motivasi kerja guru terhadap kinerja mengajar guru. Rekomendasi: Meningkatkan motivasi kerja guru dengan melakukan supervisi klinis, kunjungan kelas, pembicaraan individual dan diskusi kelompok untuk membahas permasalahan yang dihadapi oleh guru.
\end{abstract}

Kata Kunci: Kinerja Mengajar, Motivasi Kerja, Supervisi Akademik

\begin{abstract}
The problem of the low performance of teachers teaching caused by the lack of effective supervision of principal academic and teacher work motivation. The purpose of this study is to measure the influence of principal academic supervision and teacher work motivation on teacher teaching performance. Research method: descriptive analysis, quantitative approach, analysis technique using product moment correlation, determination and regression. Data collection by questionnaire. The population in this study are teachers of Vocational School in Bandung, while the unit of analysis using sampling with probability sampling technique. The results of the analysis show that the principal's academic supervision on teachers' teaching performance is positively correlated. Teacher's motivation to teacher's performance is positively correlated. Principal academic supervision and teacher work motivation on teacher teaching performance simultaneously have a strong positive correlation. In conclusion, there is a significant positive influence between principal academic supervision and teacher work motivation on teacher teaching performance. Recommendations: Improve teacher work motivation by conducting clinical supervision, class visits, individual discussions and group discussions to discuss problems faced by teachers.
\end{abstract}

Keywords: Academic Supervision, Teaching Performance, Work Motivation

\section{PENDAHULUAN}

Kinerja mengajar guru harus selalu ditingkatkan mengingat tantangan dunia pendidikan untuk menghasilkan kualitas sumber daya manusia yang mampu bersaing di era global semakin berat. Kinerja guru (performance) merupakan hasil yang dicapai oleh guru dalam melaksanakan tugas-tugas yang dibebankan kepadanya yang didasarkan atas kecakapan, pengalaman dan kesungguhan serta penggunaan waktu. Kinerja mengajar guru akan baik jika adanya selalu adanya pengawasan dari Kepala Sekolah dan motivasi yang tinggi pada tugas mengajarnya, menguasai dan mengembangkan bahan pelajaran, kedisiplinan dalam mengajar dan tugas lainnya, kreativitas dalam melaksanakan pengajaran, kerja sama dengan semua warga sekolah, penampilan kepemimpinan yang menjadi panutan siswa, kepribadian yang baik, jujur dan obyektif dalam membimbing siswa, serta bertanggung jawab terhadap tugasnya. 
Ada banyak faktor yang mengakibatkan kinerja mengajar guru masih cenderung rendah, salah satunya terjadi karena kurangnya proses pengawasan atau supervisi Kepala Sekolah. karena dalam proses pembelajaran, dibutuhkan suatu pengawasan atau supervisi yang akan menjaga dan memperbaiki bahkan meningkatkan kualitas pembelajaran. Sebagaimana yang tercantum pula dalam Permendiknas No. 14 Tahun 2007 tentang standar proses, bahwa standar proses meliputi perencanaan proses pembelajaran, pelaksanaan proses pembelajaran, penilaian hasil pembelajaran, dan pengawasan proses pembelajaran untuk terlaksananya proses pembelajaran yang efektif dan efisisen.

Maka dalam proses pendidikan, pengawasan atau supervisi merupakan bagian tidak terpisahkan dalam upaya peningkatan prestasi belajar, mutu pembelajaran dan mutu sekolah. Sahertian (2000, hlm. 19) menegaskan bahwa pengawasan atau supervisi pendidikan tidak lain dari usaha memberikan layananan kepada stakeholder pendidikan, terutama kepada guruguru baik secara individu maupun secara kelompok dalam usaha memperbaiki kualitas proses dan hasil pembelajaran.

Supervisi Kepala Sekolah terhadap guru yang biasanya dikenal sebagai supervisi akademik tersebut dapat dilakukan oleh Kepala Sekolah maupun oleh pengawas sekolah. Namun, sebagai orang yang paling dekat dan memahami kondisi serta kebutuhan guru, kepala sekolah yang harus lebih intensif membina guru dalam hal perbaikan situasi belajar mengajar. Maka tanggung jawab untuk melakukan supervisi pada guru harus dilakukan oleh Kepala Sekolah, karena menurut Permendiknas No. 13 Tahun 2007 "Seorang Kepala Sekolah harus memiliki lima jenis kompetensi, yaitu: (1) kompetensi kepribadian; (2) kompetensi manajerial; (3) kompetensi kewirausahaan; (4) kompetensi supervisi; (5) kompetensi sosial".

Pentingnya supervisi terhadap peningkatan kinerja guru diperkuat pula oleh hasil penelitian yang dilakukan oleh Yati Ruhayati (2009) tentang pengaruh supervisi akademik untuk meningkatkan kinerja guru pendidikan jasmani di sekolah dasar menunjukkan bahwa layanan supervisi mempunyai kontribusi terhadap kinerja guru. serupa pula dengan penelitian Đadang Suhardan (2006) tentang keefektifan pengawasan profesional terhadap kinerja guru yang menghasilkan salah satu temuan berupa adanya perbaikan kerja guru setelah dilaksanakannya pengawasan yang efektif oleh Kepala Sekolah.

Selain dari pengawasan atau supervisi dari Kepala Sekolah faktor lain yang dapat mempengaruhi kinerja mengajar guru adalah motivasi kerja. diasumsikan bahwa motivasi kerja yang baik akan menghasilkan kinerja yang baik pula. Motivasi pada dasarnya dapat bersumber pada diri seseorang atau yang sering dikenal sebagai motivasi internal dan dapat pula bersumber dari luar diri seseorang atau yang disebut dengan motivasi eksternal. Faktor-faktor motivasi tersebut dapat berdampak positif atau dapat pula berdampak negatif bagi seorang guru.

Kunci keberhasilan seorang Kepala Sekolah dalam menggerakkan para guru atau bawahannya terletak pada kemampuannya untuk memahami faktor-faktor motivasi kerja sedemikian rupa sehingga menjadi daya pendorong yang efektif (Siagian, 2006 hlm. 139). Kebutuhan yang dimaksud merupakan petunjuk bagi kepala sekolah untuk memenuhi kebutuhan-kebutuhan guru seefektif mungkin. Secara teoritik hubungan 
Kepala Sekolah itu apa bila dibina dan dilaksanakan dengan baik, maka motivasi kerja guru akan terpenuhi. Dengan motivasi yang baik dan tinggi muncul dari diri seorang guru, maka kesadaran gutu akan tugasnya dalam melaksanakan perencanaan, pelaksanaan, dan evaluasi pembelajaran akan selalu terlaksana. Cascio dalam Sukamalana (2003, hlm. 21) menyebutkan kemampuan dan motivasi sebagai faktor yang berinteraksi dengan kinerja. Kemampuan ditentukan oleh skill dan pengetahuan, sedangkan skill dipengaruhi oleh kecakapan, kepribadian, dan pengetahuan yang terbentuk oleh pendidikan, pengalaman latihan dan minat.

Mangkunegara (2002, hlm. 61) menyatakan bahwa motivasi terbentuk dari sikap (attitude) karyawan dalam menghadapi situasi kerja di perusahaan (situation). Motivasi merupakan kondisi atau energi yang menggerakkan diri karyawan yang terarah atau tertuju untuk mencapai tujuan organisasi perusahaan. Sikap mental karyawan yang pro dan positif terhadap situasi kerja itulah yang memperkuat motivasi karyawan untuk mencapai kinerja maksimal. Motivasi kerja guru bisa diartikan sebagai dorongan mental yang tinggi yang dimiliki oleh seorang guru dalam melakukan pekerjaan untuk mencapai tujuan sekolah. Kaitannya dengan kinerja mengajar guru, motivasi yang tinggi dan baik akan memiliki peran penting untuk membantu guru dalam melaksanakan kegiatan belajar mengajar di kelas, sehingga mutu lulusannya yang berkualitas tercapai.

Sekolah Menengah Kejuruan (SMK) merupakan subsistem pendidikan nasional yang tujuan utamanya adalah menyiapkan lulusannya untuk memasuki dunia kerja dan mengembangkan sikap profesional. Undang-Undang Sistem
Pendidikan Nasional No. 20 Tahun 2003 pasal 15 menjelaskan bahwa pendidikan kejuruan merupakan pendidikan menengah yang mempersiapkan peserta didik terutama untuk bekerja dalam bidang tertentu. Agar tujuan sekolah menengah tercapai maka diperlukan pendidik dan tenaga pendidik yang memiliki motivasi yang tinggi sehingga menghasilkan kinerja yang baik. Guru yang memiliki motivasi yang tinggi akan mampu memperlihatkan segenap potensi yang dimilikinya untuk melakukan pekerjaan dengan baik. Oleh karena itu diperlukan perhatian kepala sekolah selaku pemimpin sekolah untuk terus memberikan motivasi kepada para guru sehingga terciptanya kinerja yang baik agar tujuan sekolah tercapai.

Selain itu, peneliti juga telah melakukan studi pendahuluan melalui wawancara dengan guru dan Kepala Sekolah SMKN untuk mendapatkan informasi secara langsung terkait permasalahan yang dihadapi. Hasil studi pendahuluan memberikan gambaran yang cukup jelas bahwa masih terdapat masalah terkait kinerja guru yang kurang optimal yang diakibatkan oleh beberapa hal berikut, yaitu: 1) Sebagian guru jarang membuat RPP, ini disebabkan karena jarangnya Kepala Sekolah melakukan pengontrolan pembelajaran. 2) Sebagian guru sering memberikan tugas kepada siswa tanpa kehadiran guru di kelas, yang pada akhirnya efektivitas dan efiseinesi pembelajaran di kelas menjadi tidak tercapai di lihat dari hasil evaluasi pembelajaran yang mana banyak siswa tidak mencapai target minimal. 3) Masih ada guru yang mengalami kesulitan dalam proses belajar mengajar, dikarenakan Kepala Sekolah jarang melakukan pembinaan, pendampingan, perbaikan dan evaluasi kepada guru. Dan 4) Disiplin kerja guru yang masih kurang baik ditunjukkan oleh 
tingkat kehadiran guru, sering terlambatnya guru datang ke sekolah dan masuk ke kelas yang menyebabkan kondisi di dalam kelas menjadi kurang terkendali ketika tidak ada guru atau guru terlambat.

Fenomena di atas, mengandung arti bahwa pengelolaan proses belajar mengajar, motivasi guru, bimbingan terhadap guru melalui supervisi akademik yang dilakukan Kepala Sekolah serta kinerja mengajar guru masih perlu ditingkatkan.
Dari beberapa faktor penentu kinerja mengajar guru tersebut yang paling menarik diteliti adalah pengaruh supervisi akademik Kepala Sekolah dan motivasi kerja guru terhadap kinerja mengajar guru, dengan menjadikan pengaruh supervisi akademik Kepala Sekolah dan motivasi kerja guru sebagai variabel bebas 1 dan 2 atau $X_{1}$ dan $X_{2}$. Sedangkan yang dijadikan variabel terikat adalah kinerja mengajar guru $(\mathrm{Y})$.

\section{METODE PENELITIAN}

Metode penelitian; analisis deskriptif, pendekatan kuantitatif, teknik analisis dengan korelasi product moment, determinasi dan regresi dengan menggunakan Software SPSS 20. Pengumpulan data melalui angket. Melalui pendekatan kuantitatif, dapat diketahui kontribusi dari variabel yang diteliti yaitu supervisi akademik kepala sekolah dan motivasi kerja guru terhadap variabel $\mathrm{Y}$ yaitu kinerja mengajar guru dengan menggunakan perhitungan statistik.

Populasi dalam penelitian ini yaitu guruguru SMK Negeri di Kota Bandung berjumlah 1024 orang, dengan sampel berjumlah 288 responden dengan teknik Simple Random Sampling.

Adapun penentuan jumlah sampel peneliti melakukan penentuan sampel berdasarkan rumus Taro Yamane sebagai berikut:

$$
\mathrm{n}=\frac{N}{N \cdot d^{2}+1}
$$

Keterangan:

$\mathrm{n}=$ jumlah sampel

$$
\begin{aligned}
& \mathrm{N}=\text { jumlah populasi } \\
& \mathrm{d}=\text { presisi yang ditetapkan }
\end{aligned}
$$

Diketahui jumlah populasi guru sebanyak 1024 guru dan tingkat presisi yang ditetapkan sebesar 5\%. Jadi berdasarkan rumus tersebut, maka sampel representative dari jumlah populasi guru adalah $\mathbf{2 8 8}$ orang guru.

Adapun sampel masing-masing sekolah dilakukan perhitungan dengan menggunakan rumus dari Sugiyono dalam Akdon (2008, hlm. 108), yaitu:

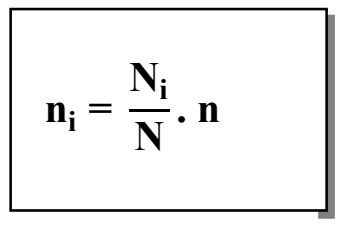

Keterangan:

$\mathrm{n}_{\mathrm{i}} \quad=$ jumlah sampel menurut stratum

$\mathrm{n} \quad=$ jumlah sampel seluruhnya

$\mathrm{N}_{\mathrm{i}} \quad=$ jumlah populasi menurut stratum

$\mathrm{N} \quad=$ jumlah populasi seluruhnya

\section{HASIL PENELITIAN DAN PEMBAHASAN}

Analisis dilakukan setelah uji prasyarat analisis dilakukan yaitu dengan uji normalitas data dan uji linieritas data yang menunjukkan data berdistribusi normal dan linier. Hasil pengujian persyaratan analisis tersebut menunjukkan bahwa skor setiap variabel penelitian telah memenuhi 
syarat untuk dilakukan pengujian statistik lebih lanjut, yaitu pengujian hipotesis. Pengujian hipotesis penelitian tersebut dilakukan dengan menghitung koefesien korelasi, taraf signifikansi, determinasi dan analisis regresi. Berdsarkan hail pengujian hipotesis tersebut diperoleh hasil sebagaimana dalam gambar berikut.

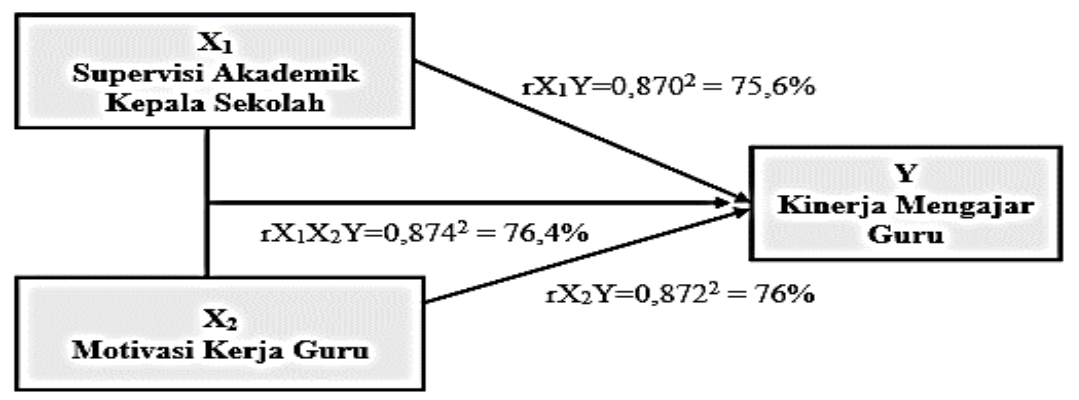

Gambar 1 Hasil Koefisien Korelasi antar Variabel Bebas dan Terikat

Berdasarkan hasil analisis korelasi, diperoleh nilai $p$ value $=0,000$. Nilai $p$ value tersebut kurang dari taraf signifikansi 0,05. Hal ini berarti hipotesis yang menyatakan bahwa terdapat pengaruh Supervisi Akademik kepala sekolah dan Motivasi Kerja guru terhadap kinerja mengajar guru "Diterima".

Berdasarkan perhitungan uji signifikansi ganda diperoleh harga $F_{\text {hitung }}$ sebesar 461,611 sedangkan $\mathrm{F}_{\text {tabel }}$ pada tingkat kepercayaan 95\% dengan $\mathrm{dk}(\mathrm{n}-2)=286$ diperoleh $\mathrm{F}_{\text {tabel }}$ sebesar 1, 2151. Setelah diketahui harga $F_{\text {hitung }}$ dan $F_{\text {tabel }}$ ternyata $F_{\text {hitung }} 461,611>\mathrm{Ft}_{\mathrm{abel}} 1$ 1, 2151. Dengan demikian dapat disimpulkan bahwa terdapat pengaruh positif yang signifikan dan sangat kuat antara supervisi akademik kepala sekolah dan Motivasi Kerja guru terhadap kinerja mengajar guru.

Berdasarkan perhitungan diperoleh korelasi antara supervisi akademik kepala sekolah dan motivasi kerja guru terhadap kinerja mengajar guru sebesar $r=\mathbf{0 , 8 7 4}$ jika melihat tolok ukur atau kriteria harga koefesien korelasi menunjukkan tingkat korelasi positif dan sangat kuat.

Dengan menggunakan regresi ganda, diperoleh hubungan positif antara supervisi akademik kepala sekolah dan motivasi kerja guru terhadap kinerja mengajar guru dalam bentuk persamaan linier. Pengaruh positif dan signifikan antara supervisi akademik kepala sekolah dan motivasi kerja guru terhadap kinerja mengajar guru ditunjukkan dalam persamaan;

$$
\widehat{\mathbf{Y}}=1,283+0,291 \mathrm{X} 1+0,392 \mathrm{X} 2
$$

Dengan persamaan regresi tersebut dapat diinterpretasikan bahwa jika supervisi akademik kepala sekolah dan motivasi kerja guru dengan kinerja mengajar guru diukur dengan instrument yang dikembangkan dalam penelitian ini, maka setiap perubahan skor variabel supervisi akademik kepala sekolah dan motivasi kerja guru sebesar satu satuan dapat diestimasikan skor kinerja mengajar guru akan berubah sebesar 0,291 satuan variabel supervisi akaddemik $\left(\mathrm{X}_{1}\right)$ dan 0,392 satuan variabel motivasi kerja $\left(\mathrm{X}_{2}\right)$.

Secara empiris, hasil penelitian ini menginformasikan bahwa supervisi akademik kepala sekolah dan motivasi kerja guru secara bersama berpengaruh terhadap kinerja mengajar guru. Besarnya pengaruh supervisi akademik dan motivasi kerja guru sebesar $76,4 \%$ mempengaruhi kinerja guru, hal ini menunjukkan kontribusi yang sangat signifikan. 
Hal ini diperkuat oleh hasil penelitian sebelumnya yang menunjukkan bahwa: (1) Terdapat pengaruh positif dan signifikan supervisi akademik kepala sekolah terhadap kinerja mengajar guru sebesar 24,8\%. Ini mengandung arti bahwa semakin baik supervisi akademik kepala sekolah maka akan semakin baik pula kinerja mengajar guru (2) Terdapat pengaruh positif dan signifikan antara motivasi berprestasi guru terhadap kinerja mengajar guru sebesar 45,5\%. Ini mengandung arti bahwa semakin tinggi motivasi berpresasi guru maka akan semakin baik pula kinerja mengajarnya (3) Terdapat pengaruh positif dan signifikan secara bersama-sama antara supervisi akademik kepala sekolah, motivasi berprestasi guru terhadap kinerja mengajar guru sebesar 52,2\%. Hal ini menunjukkan bahwa semakin baik supervisi akademik kepala sekolah dan semakin tinggi motivasi berpresatasi guru maka semakin baik kinerja mengajar guru, (Kodariah, Herawan, Sutrasih, \& Indonesia, 2016)

Dengan demikian supervisi akademik kepala sekolah hendaknya dilakukan secara teratur dan berkala dengan mengagendakan jadwalnya dalam program perencanaan supervisi dan menggunakan pendekatan supervisi klinis. Dalam kegiatan supervisi tersebut terdapat kegiatan yang bertujuan untuk meningkatkan motivasi kerja guru, hal ini bertujuan menciptakan iklim kerja yang kondusif baik antara guru dan kepala sekolah, antara guru dan guru dan antara semua pihak yang terkait dengan sekolah, dengan demikian kinerja guru akan meningkat.

Seperti halnya peran kepala sekolah dalam meningkatkan kinerja guru, faktor lain yang dapat mempengaruhi kinerja guru di sekolah adalah motivasi berprestasi yang ada dalam jiwa guru. Bila guru dalam melakukan pekerjaan mempunyai motivasi berprestasi, ia akan melakukan pekerjaan dengan sungguh-sungguh untuk mencapai keberhasilan. Ketika guru medapatkan bimbingan, arahan dan dorongan dari kepala sekolah dengan baik, maka guru kemudian akan merasa diperhatikan dan diarahkan kemudian direalisasikan dalam kinerja yang baik dalam proses pembelajaran. Tapi, jika guru tidak atau kurang mendapat bimbingan dan dorongan dari kepala sekolah, maka guru pun merasa tidak diperhatikan dan diarahkan yang mengakibatkan kinerjanya kurang baik tidak terarah. Dengan demikian, supervisi dan motivasi berprestasi guru secara bersama-sama berpengaruh terhadap kinerja mengajar guru, hal ini sebagaimana telah dijelaskan di bagian sebelumnya pada masingmasing variabelnya.

Kinerja atau performance ialah sebagai hasil kerja yang dapat dicapai oleh seseorang atau sekelompok orang dalam suatu organisasi, sesuai dengan kewenangan dan tugas tanggung jawab masing-masing, dalam upaya untuk mencapai tujuan yang diharapkannya. Sedangkan mengajar ialah suatu proses mengorganisasi dan membimbing anak didik dengan bahan pengajaran yang menimbulkan proses belajar, (Usman, 2009, hlm. 6). Kemudian guru ialah yang berperan sebagai pembimbing dan kreator proses belajar mengajar pada peserta didik atau siswa. Dengan demikian kinerja mengajar guru diartikan sebagai hasil kerja guru dalam melaksanakan tugasnya sebagai pendidik dan pengajar dalam mengorganisasikan dan membimbing anak didik dengan mempersiapkan keterampilan, kompetensi dan berbagai admistratif yang diperlukan dalam proses pembelajaran.

Adapun untuk menilai kinerja guru tersebut, menurut Usman (2002, hlm. 9) 
mengatakan bahwa: "untuk menilai kemampuan mengajar seorang calon guru atau guru dapat dilihat dari 3 aspek, yaitu: (1) keterampilan dalam menyusun rencana pengajaran, (2) keterampilan melaksanakan kegiatan belajar mengajar di kelas, dan (3) keterampilan melaksanakan hubungan antar pribadi”. Dengan demikian pengertian kinerja mengajar guru ialah suatu prestasi yang dicapai oleh seorang guru dalam melaksanakan tugasnya selama periode tertentu yang diukur berdasarkan tiga indikator yaitu penguasaan bahan ajar, kemampuan mengelola dan komitmen dalam melaksanakan pembelajaran, dan mengevaluasi pembelajaran, (Suhayati, 2013, hlm. 24).

Pengertian yang hampir senada, yang diungkapkan oleh (Rismawan, 2015, hlm. 17), ia mengungkapkan bahwasannya kinerja mengajar guru diartikan sebagai penampilan kerja seorang guru dalam pembelajaran, sebagai realisasi dari kompetensi yang dimilikinya untuk memperoleh hasil belajar peserta didik yang optimal.

Jika mengacu pada hasil penelitian yang dilakukan oleh (Kodariah, Herawan, \& Sutrasih, 2016), maka, secara umum, "kinerja menagajar guru tidak akan terlaksana dengan baik apabila salah satu dimensi atau indikator yang melingkupinya tidak terpenuhi”. Adapun indikator-indikator yang digunakan dalam penelitian ini untuk mengukur tingkat kinerja guru beserta faktor-faktor yang mempengaruhinya adalah sebagaimana telah dijelaskan pada bagian kajian pustaka mengacu terhadap beberapa pendapat yang dikemukakan di antaranya oleh Sa'ud (2012, hlm. 50) bahwa untuk keperluan analisis terhadap guru sebagai pengajar, maka kompetensi kinerja profesi keguruan dalam penampilan aktual dalam proses kegiatan belajar mengajar setidaknya memiliki tempat kemampuan, yaitu: (1) Merencanakan proses belajar mengajar; (2) Melaksanakan dan memimpin/mengelola proses belajar mengajar; (3) Menilai kemajuan proses belajar mengajar; dan (4) Menguasai bahan pengajaran.

Kemudian secara spesifik indikator yang digunakan dalam penelitian ini adalah mengacu pada pendapat Nasution (2003, hlm. 184-185) dimana dimensi dan indikator kinerja mengajar guru meliputi: (a) perencanaan pembelajaran; (b) pelaksanaan pembelajaran; (c) evaluasi pembelajaran. Dengan melaksanakan dimensi ini dengan baik, maka mutu pendidikan akan tercapai. Hal ini juga sesuai dengan yang dijelaskan dalam Undang-undang No. 20 Tahun 2003 Tentang Sistem Pendidikan Nasional, Bab XI Pasal 39 Ayat (2) adalah merencanakan dan melaksanakan proses pembelajaran, menilai hasil pembelajaran, melakukan pembimbingan dan pelatihan. Dimana secara khusus dijelaskan terkait dengan tiga bidang pokok yang paling penting dan perlu diperhatikan oleh guru, yaitu: Pertama; Mempersiapkan pengajaran, bidang ini mencakup seluruh kegiatan yang harus dilaksanakan seorang guru sebelum memberikan atau menyampaikan materi pengajaran; meninjau kembali materi pengajaran; mengembangkan batas-batas latihan atau perencanaan memastikan bahwasanya seluruh bahan-bahan, alat bantu latihan, dan ruang kelas telah dipersiapkan; mempersiapkan daftar nilai untuk menentukan tingkatan dan pengetahuan peserta latihan dan lain-lain. Kedua; Melaksanakan pengajaran, tanggung jawab ini meliputi pemberian partisipasi yang besar, dengan menggunakan landasan keterampilan, pemahaman materi dan urutan pengajaran, pelaksanaan teknikteknik pertanyaan yang efektif dan menggunakan alat bantu latihan dalam rangka peningkatan proses 
belajar. Ketiga; Menilai hasil-hasil belajar pengajaran tersebut, tanggung jawab ini meliputi penilaian prestasi peserta didik secara objektif, mengumpulkan data materi pengajaran dan bahanbahan serta memikirkan kinerja gurunya itu sendiri.

Berdasarkan temuan yang diperoleh dari hasil analisis data penelitian pada indikatorindikator tersebut di atas yang terkait dengan variabel kinerja mengajar guru, menunjukkan bahwasannya kinerja mengajar guru berdasarkan pada penghitungan WMS didapatkan nilai rata-rata sebesar 3,72, atau berada pada kategori Sangat tinggi. Hal tersebut terukur dari skor rata-rata indikator; 1) Penyusunan rencana pembelajaran 3,73; 2) Pelaksanaan interaksi belajar mengajar 3,70; dan 3) penilaian dan tindak lanjut hasil penilaian prestasi belajar siswa 3,74.

Berdasarkan pada pendapat tersebut di atas, selain dari variabel yang tidak dibahas dalam penelitian ini yang dapat mempengaruhi kinerja mengajar guru, juga dituntut agar kepala sekolah memiliki banyak penguasaan keterampilan terhadap berbagai pendekatan instruksional administratif dalam menilai ataupun membina guru, tentunya banyak sekali pendekatan yang dapat digunakan dalam meningkatkan motivasi guru melalui supervisi akademik yang dilakukan kepala sekolah untuk meningkatkan kinerja guru, dengan demikian hal ini mengisyaraktakn perlunya suatu model kolegial dalam pelaksanaan supervisi akademik, sehingga dengan sendirinya guru termotivasi dalam ningkatkan kualitas pembelajarannya, karena guru sendiri terlibat dalam upaya perbaikan dan peningkatan mutu pembelajaran tersebut melalui pelaksanaan model supervisi akademik kolegial.
Kendala yang dihadapi kepala sekolah dalam meningkatkan kinerja guru yaitu guru tidak membuka pelajaran dengan appersepsi pada saat pelaksanaan pembelajaran dan guru banyak yang tidak melakukan pengklasifikasian kemampuan peserta didik berdasarkan hasil penilaian yang kemudian menyusun program tindak lanjutnya.

Selanjutnya setelah guru mampu mengklasifikasikan kemampuan siswa berdasarkan pada hasil penilaian adalah menyusun program tindak lanjut untuk masing-masing klasifikasi tersebut. Dengan demikian guru harus memiliki kemampuan dalam membantu siswa mengatasi masalah belajar yang terdiri dari; Pertama; program perbaikan; 1) Cara yang ditempuh; kegiatan pokok dalam pengajar perbaikan terletak pada usaha memperbaiki kesalahan-kesalahan atau penyimpangan yang terjadi pada murid berkenaan dengan mata pelajaran yang dipelajarinya. 2) materi dan waktu pelaksanaan program perbaikan; setelah mengikuti test atau ujian komptensi dasar tertentu, setelah mengikuti test/ujian blok atau sejumlah komptensi dasar dalam satu kesatuan, setelah mengikuti test atau ujian komptensi dasar atau blok terakhir. Kedua; program pengayaan; pengajaran pengayaan adalah suatu bentuk pengajaran yang khusus diberikan kepada murid-murid yang sangat cepat belajar. Ketiga; program akselerasi (percepatan). Program akselerasi memberikan kesempatan kepada peserta didik untuk melalui masa belajar di sekolah dengan waktu yang relatif cepat. Agar program percepatan secara alami dapat dilaksanakan dengan baik, maka program-program pembelajaran perlu di kemas dalam satuan-satuan, dan disiapkan dengan cermat serta rinci dalam bentuk modul atau paket-paket pembelajaran. 
Dengan demikian dalam mengatasi kendala yang dihadapi dalam hal tersebut untuk meningkatkan kinerja mengajar kepala sekolah harus memiliki program peningkatan kompetensi guru dalam menganaisis hasil penilaian untuk menentukan klasifikasi kemampuan siswa dan menentukan program tindak lanjutnya.

\section{SIMPULAN}

Terdapat pengaruh positif dan signifikan antara supervisi akademik kepala sekolah terhadap kinerja mengajar guru. Hal ini berarti apabila supervisi akademik kepala sekolah efektif, maka kinerja guru akan menjadi tinggi.

Terdapat pengaruh positif dan signifikan antara motivasi kerja guru terhadap kinerja mengajar guru. Hal ini berarti motivasi kerja yang tinggi mempunyai pengaruh dalam peningatan kinerja guru.

Terdapat pengaruh yang positif dan signifikan antara supervisi akademik kepala sekolah dan motivasi kerja guru terhadap kinerja mengajar guru. Hipotesis yang peneliti ajukan diterima artinya bahwa terdapat pengaruh positif dan signifikan antara supervisi akademik kepala sekolah dan motivasi kerja guru terhadap kinerja mengajar guru. Kemudian persamaan regresi yang diperoleh ialah linier, hal ini diartikan bahwa semakin efektif supervisi akademik kepala sekolah dan motivasi kerja guru yang tinggi maka akan semakin tinggi juga kinerja mengajar guru.

\section{REKOMENDASI}

Pemberian reward atas prestasi kerja dalam bentuk penghargaan agar guru lebih termotivasi lagi dalam mengerjakan tugasnya. Peningkatan motivasi kerja guru, yaitu dengan melakukan supervisi klinis dengan melakukan kunjungan kelas, pembicaraan individual dan diskusi kelompok untuk membahas permasalahan yang dihadapi oleh guru

Memberikan bimbingan kepada guru secara rutin untuk melakukan evaluasi diri dalam memberikan pelajaran kepada siswanya. Memberikan penghargaan secara verbal terhadap prestasi guru yang telah disupervisi sehingga guru lebih meningkatkan kinerja dalam mengajar. Memberikan bimbingan kepada guru dalam pelaksanaan kegiatan pembelajaran dan memberikan masukan untuk perbaikan penyempurnaan perangkat pembelajaran yang dibuat oleh guru.

\section{DAFTAR PUSTAKA}

Kodariah, W., Herawan, E., \& Sutrasih, C. (2016). Supervisi Akademik Kepala Sekolah, Motivasi Berprestasi Guru dan Kinerja Mengajar Guru. Jurnal Administrasi Pendidikan, Vol.XXIII (2), 126-129.
Mangkunegara, Anwar P. (2002). Manajemen Sumber Daya Manusia. Bandung: PT.Remaja Rosda Karya

Mangkunegara, Anwar P. (2009). Evaluasi Kinerja SDM. Bandung: PT Refika Aditama

Nasution. (2003). Kinerja Mengajar Guru. Jakarta: Bina Aksara. 
Rismawan, E. (2015). Pengaruh Supervisi Kepala Sekolah dan Motivasi Berprestasi Guru Terhadap Kinerja Mengajar Guru. Jurnal Administrasi Pendidikan, XXII (1), 115-116.

Ruhayati, Yati, dkk. (2009). Kontribusi Layanan Supervisi, Kepemimpinan Kepala Sekolah dan Fasilitas Pembelajaran terhadap Kinerja Guru Pendidikan Jasmani SMPN se-Kota Cimahi. Jurnal Penelitian. 10(2)

Sa’ud, U. (2010). Pengembangan Profesi Guru. Bandung: Alfabeta.

Sahertian, Peit, (2000) Konsep dasar dan Teknik Supervisi Pendidikan Jakarta: PT Rineka Cipta.

Sahertian, Piet, A. dan Ida Aleida Sahertian, (2000). Supervisi Pendidikan dalam Rangka Inservice Education. Jakarta: Rineka Cipta.

Siagian, S. P. (2006). Manajemen Sumber Daya Manusia. Jakarta: Bumi Aksara.

Siagian. (2002). Kiat Meningkatkan Produktivitas Kerja. Jakarta: Rineka Cipta.
Suhardan, Dadang. (2010). Supervisi Profesional Layanan Meningkatkan Mutu Pembelajaran di Era Otonomi Daerah. Bandung: Alfabeta.

Suhayati, I. Y. (2013). Supervisi Akademik Kepala Sekolah, Budaya Sekolah Dan Kinerja Mengajar Guru. Jurnal Administrasi Pendidikan UPI, XIII (1), 124-142.

Sukamalana. (2003). Faktor-Faktor Determinan yang Berkontribusi terhadap Kinerja Dosen PT. Swasta. Disertasi SPS UPI.

Undang-Undang No. 14 Tahun (2005) Tentang Guru dan Dosen.

Undang-Undang No. 20 Tahun (2003) Tentang Sistem Pendidikan Nasional. Bandung: CV Nuansa Aulia.

Usman, Husaini. (2009). Manajemen, Teori, Praktik, dan Riset Pendidikan. Jakarta: Bumi Aksara. 